\title{
PENGARUH DISIPLIN KERJA, MOTIVASI KERJA, KEPUASAN KERJA DAN KOMPETENSI TERHADAP KOMITMEN ORGANISASI
}

\author{
Nurlaely M. dan Asri Laksmi Riani \\ Pascasarjana Universitas Sebelas Maret Surakarta, Jl. Ir. Sutami 36 A Surakarta \\ Email: nurlelimanurung@yahoo.com
}

\begin{abstract}
The purpose of this study to determine and analyze the effect of work discipline, work motivation, job satisfaction, and work competence of the organization's commitment to employees in RSO Prof. Dr. $R$ Soeharso Surakarta. This research was explanatory research with survey research design. Data used primary data. The population of all employees who work in RSO Prof. Dr. R. Soeharso totaling 626 people, were taken a sample of 244 people with purposive sampling technique. The research instrument used a questionnaire with a scale linkert. The data analysis includes validation test, reliability and multiple regression analysis, $t$-test, $F$ and $R 2$. The results showed discipline work positive and significant effect on organizational commitment, motivation positive and significant effect on organizational commitment, job satisfaction positive and significant effect on organizational commitment, competence work positive and significant effect on organizational commitment, and the discipline of work, work motivation, job satisfaction and work competence significant effect together against the organization's commitment to employee hospital Orthopedics Prof. Dr. R. Soeharso Surakarta
\end{abstract}

Keywords: Work discipline, work motivation, job satisfaction, and competence, organization commitment.

\begin{abstract}
Abstrak
Tujuan penelitian ini untuk mengetahui dan menganalisis pengaruh disiplin kerja, motivasi kerja, kepuasan kerja, dan kompetensi kerja terhadap komitmen organisasi pada karyawan di RSO Prof. Dr. R Soeharso Surakarta. Penelitian ini berjenis penelitian eksplanatori dengan desain penelitian survei. Jenis data yang digunakan data primer. Populasi yang digunakan seluruh karyawan yang bekerja di RSO Prof Dr R. Soeharso yang berjumlah 626 orang, diambil sampel sebanyak 244 orang dengan teknik purposive sampling. Instrumen penelitian menggunakan kuesioner dengan skala linkert. Analisa data meliputi uji validasi, reliabilitas dan analisa regresi berganda, uji t, uji $F$ dan $R^{2}$. Hasil penelitian menunjukkan disiplin kerja berpengaruh positif dan signifikan terhadap komitmen organisasi, motivasi kerja berpengaruh positif dan signifikan terhadap komitmen organisasi, Kepuasan kerja berpengaruh positif dan signifikan terhadap komitmen organisasi, Kompetensi kerja berpengaruh positif dan signifikan terhadap komitmen organisasi, dan Disiplin kerja, motivasi kerja, kepuasan kerja dan kompetensi kerja berpengaruh signifikan secara bersama-sama terhadap komitmen organisasi pada karyawan RS. Ortopedi Prof. Dr. R. Soeharso Surakarta.
\end{abstract}

Kata Kunci: Disiplin kerja, motivasi kerja, kepuasan kerja, kompetensi kerja, komitmen organisasi 


\section{Pendahuluan}

Era globalisasi berdampak pada segala aspek dan membawa berbagai perubahan paradigma dan persaingan bisnis terlebih lagi dengan dicanangkannya MEA. Semakin banyaknya kompetitor dan tingginya persaingan dalam segala aspek, maka SDM dalam organisasi dituntut memiliki pengetahuan, kemampuan, motivasi dan kompetensi yang tinggi, bahkan SDM perlu peningkatan dalam bidang spesialisasinya. Motivasi kerja yang ada pada diri seseorang menjadi frame of reference dalam mewujudkan suatu perilaku yang diarahkan pada tujuan pribadi. Hal ini perlu ditunjang oleh disiplin kerja yang bagus dan komitmen terhadap segala peraturan yang ada dan mentaati perintah serta kebijakan organisasi dan pimpinan sehingga setiap karyawan yang ada mampu berperan aktif dalam mewujudkan visi dan misi dari organisasi.

Tuntutan masyarakat yang semakin kompleks, peningkatan kemampuan dan pemberdayaan sumber daya manusia merupakan modal penting bagi kelancaran organisasi, disamping adanya kelengkapan sarana dan prasarana. Menurut Handoko (2014) manusia harus bertindak sebagai pengelola dan pelaksananya sebab manusia merupakan kunci keberhasilan dalam mengerjakan suatu pekerjaan, untuk itu dibutuhkan Karyawan yang mampu dan terampil, dalam melaksanakan tugas.

Rumah Sakit Ortopedi Prof. Dr. R. Soeharso Surakarta sebagai institusi layanan sosial dan merupakan rumah sakit pusat rujukan nasional yang berperan aktif dalam pelaksanaan pemberian jasa layanan masyarakat. Sebagai pemberi jasa layanan sosial masyarakat harus mampu mengelola sumber daya manusia atau karyawan agar menjadi pelayan masyarakat yang baik khususnya mereka yang sedang membutuhkan perhatian yang lebih karena kondisinya yang sedang kurang sehat secara fisik. Manajemen sumber daya manusia merupakan bagian dari organisasi.
Penelitian ini merupakan pengembangan dari hasil Studi pada PT. Dada Indonesia yang dilakukan Mangkunegara dan Octorend (2015) dengan Pengaruh Disiplin Kerja, Motivasi Kerja, Kepuasan Kerja dan Komitmen Organisasi pada karyawan di Perusahaan tahun 2015 yang dilakukan oleh Sriekaningsih dan Setyadi (2015) mengenai pengaruh kompetensi, motivasi dan budaya organisasi kearah komitmen organisasi dan kinerja pada dosen state university di Kalimantan Timur tahun 2015.

Tujuan penelitian ini sebagai berikut: (1) Menganalisis pengaruh disiplin kerja terhadap komitmen organisasi; (2) Menganalisis pengaruh motivasi terhadap komitmen organisasi; (3) Menganalisis pengaruh kepuasan kerja terhadap terhadap komitmen organisasi; (4) Menganalisis pengaruh kompetensi terhadap komitmen organisasi; (5) Menganalisis pengaruh disiplin kerja, motivasi kerja, kepuasan kerja, dan kompetensi kerja terhadap komitmen organisasi pada karyawan di RSO Prof. Dr. R Soeharso Surakarta.

\section{Tinjauan Pustaka}

\section{Motivasi}

Motivasi merupakan masalah yang kompleks dalam perubahan sebab kebutuhan dan keinginan setiap anggota rumah sakit berbeda-beda. Rumah sakit perlu memahami motivasi para Karyawannya, sebab faktor ini akan menentukan jalannya rumah sakit dalam mencapai tujuannya, agar perilaku Karyawan sesuai dengan tujuan visi dan misi organisasi maka harus ada perpaduan yang serasi antara motivasi dengan pemenuhan kebutuhan mereka serta keinginan rumah sakit. Untuk memenuhi kebutuhan Karyawan, rumah sakit menuangkannya dalam kebijakan. Kebijakan rumah sakit yang sesuai dengan kebutuhan, upaya, keinginan serta harapan Karyawan akan berdampak positif terhadap kinerja Karyawan (Halim, 2013). 


\section{Kepuasan Kerja}

Kepuasan kerja adalah perasaan seseorang terhadap pekerjaannya (As'ad, 2007). Kepuasan kerja bagi seorang Karyawan baik itu sebagai pimpinan maupun hanya pelaksana laksana bensin pada kendaraan bermotor, sebab kendaraan tanpa bensin tidak akan mampu berjalan dengan lancar. Menurut Davis (2008) kepuasan kerja adalah suatu perasaan yang menyokong diri Karyawan yang berhubungan dengan pekerjaan maupun dengan dirinya. Konsepsi kepuasan kerja Karyawan sebagai hasil interaksi manusia dengan lingkungannya dan terkait dengan masing-masing individu serta situasi lingkungan kerja. Menurut Bloom (dalam As'ad, 2007) kepuasan kerja adalah sikap umum yang merupakan hasil dari beberapa sikap khusus terhadap faktor-faktor pekerjaaan, penyesuaian diri dan hubungan sosial individual di luar kerja. Adanya motivasi, kedisiplinan yang tinggi serta kepuasan kerja diharapkan seorang Karyawan mampu menghasilkan kinerja yang optimal.

\section{Kinerja}

Menurut Minner (dalam Pramudita 2008) kinerja adalah tingkat keberhasilan seseorang Karyawan dalam melaksanakan pekerjaan, jadi kinerja merupakan hasil yang dicapai oleh seseorang menurut ukuran yang berlaku untuk suatu pekerjaan.

\section{Komitmen}

Komitmen sebagai derajat keterikatan relative dari individu terhahap kepentingan organisasi dan derajat keterlibatannya dalam organisasi, menurut Luthans (2008) memiliki 3 faktor yaitu : a) Keinginan kuat untuk tetap menjadi anggota suatu organisasi; b) Kesediaan untuk berusaha sebaik mungkin demi kebaikan organisasi; c) Kepercayaan dan penerimaan yang kuat terhadap nilainilai dan tujuan organisasi tersebut. Untuk mencapai komitmen yang tinggi dibutuhkan pengelolaan Karyawan dengan benar. Menurut Trianggraery (2013) komitmen terhadap kerja sangat berperan dalam mencapai keberhasilan rumah sakit. Karyawan yang memiliki komitmen yang kuat mempunyai keterikatan yang besar dengan institusi ia bekerja, sebagai bukti tidak berkeinginan untuk meninggalkan tempat kerja karena mempunyai loyalitas yang tinggi. Hasil penelitian Schein yang dikutip oleh Celine (2007) menunjukkan para pekerja akan merasa lebih puas dan memegang teguh komitmennya sesuai dengan nilai-nilai rumah sakit, dalam interaksi seharihari antara atasan dengan bawahan kadang muncul berbagai asumsi dan harapan lain. Adanya kesesuaian asumsi dan harapan Karyawan akan menimbulkan kepuasan kerja dan menjadi salah satu faktor penentu keberhasilan rumah sakit. Menurut Spencer (1993) salah satu indikator kompetensi akan terlihat dari motivasi karakteristik individu; semakin tinggi motivasi seseorang maka semakin berkompeten hal ini akan terlihat dari hasil kerja yang maksimal sesuai dengan kemampuan dan cara kerja yang dilakukan.

\section{Metode Penelitian}

Penelitian dilakukan di Rumah Sakit Ortopedi Prof. Dr. R. Soeharso Surakarta. Penelitian ini merupakan penelitian eksplanatori dengan desain penelitian survei. Jenis data yang digunakan data primer. Populasi yang digunakan seluruh karyawan yang bekerja di RSO Prof Dr R. Soeharso yang berjumlah 626 orang, diambil sampel sebanyak 244 orang dengan teknik purposive sampling. Variabel bebas dalam penelitian ini adalah disiplin kerja, motivasi kerja, kepuasan kerja dan kompetensi kerja, sedangkan variabel terikatnya adalah komitmen organiasi. Instrumen penelitian menggunakan kuesioner dengan skala linkert. Analisa data meliputi uji validasi, reliabilitas dan analisa regresi berganda, uji t, uji $F$ dan $\mathrm{R}^{2}$

\section{Hasil Dan Pembahasan}

\section{Analisis Koefisien Determinasi $\left(\mathbf{R}^{2}\right)$}

Nilai koefisien derterminasi $\left(\mathrm{R}^{2}\right)$ model persamaan ini sebagaimana terlihat pada tabel 1 berikut. 
Tabel 1. Hasil Analisis Koefisien Determiasi $\left(\mathbf{R}^{2}\right)$

Model Summary

\begin{tabular}{|c|c|c|c|c|}
\hline Model & $\mathbf{R}$ & R Square & Adjusted R Square & Std. Error of the Estimate \\
\hline 1 & $.615^{\mathrm{a}}$ & .378 & .367 & 6,690 \\
\hline
\end{tabular}

Perhitungan nilai $\mathrm{R}^{2}$ diperoleh angka sebesar 0,378 , artinya bahwa $37,80 \%$ variasi variabel komitmen organisasi dapat dijelaskan oleh variabel disiplin kerja, motivasi kerja, kepuasan kerja dan kompetensi kerja, sedangkan sisanya yaitu $62,2 \%$ merupakan variabel yang tidak diteliti dalam penelitian

\section{Uji F}

Uji F dimaksudkan untuk menguji apakah model regresi dengan variabel dependen dan variabel independen mempunyai pengaruh signifikan secara simultan. Berdasarkan uji hipotesis dengan uji $\mathrm{F}$ diketahui seperti tampak pada tabel berikut : ini.

Tabel 2.

Hasil Uji F-test

ANOVA $^{\mathrm{a}}$

\begin{tabular}{lcccccc}
\hline & Model & Sum of Squares & Df & Mean Square & F & Sig. \\
\hline & Regression & 3190,918 & 4 & 797,729 & 36,262 & $.000^{\mathrm{b}}$ \\
1 & Residual & 5257,765 & 239 & 21,999 & & \\
& Total & 8448,672 & 243 & & & \\
\hline a. & Dependent Variable: Komitmen organisasi (Y) \\
b. & Predictors: (Constant), Kompetensi Kerja (X4), Kepuasan Kerja (X3), \\
& Disiplin Kerja (X1), Motivasi Kerja (X2) \\
Sumber: Analisis Data primer, 2016.
\end{tabular}

Berdasarkan hasil analisis didapatkan berpengaruh signifikan terhadap variabel $\mathrm{F}_{\text {hitung }}>\mathrm{F}_{\text {tabel }} ; 36,262>2,760$ dan nilai sign. terikat yaitu komitmen organisasi. $0,000<0,05$ maka Ho ditolak dan $\mathrm{H}_{\mathrm{a}}$ diterima, hal ini berarti variabel disiplin kerja, motivasi kerja, kepuasan kerja, dan kompetensi kerja

\section{Uji t}

Berdasarkan hasil analisis dapat diketahui hasil uji t seperti tampak pada tabel berikut:

Tabel 3. Rekapitulasi Hasil Uji t

\begin{tabular}{lcccc}
\hline \multicolumn{1}{c}{ Variabel } & Koefisien Regresi & $\mathbf{t}_{\text {hitung }}$ & $\mathbf{t}_{\text {tabel }}$ & Sig. $(\alpha=\mathbf{0 , 0 5})$ \\
\hline Disiplin Kerja $\left(\mathrm{X}_{1}\right)$ & 0,501 & 3,125 & 2,042 & 0,002 \\
Motivasi Kerja $\left(\mathrm{X}_{2}\right)$ & 1,072 & 7,161 & 2,042 & 0,000 \\
Kepuasan Kerja $\left(\mathrm{X}_{3}\right)$ & 0,777 & 6,606 & 2,042 & 0,000 \\
Kompetensi Kerja $\left(\mathrm{X}_{4}\right)$ & 0,725 & 5,002 & 2,042 & 0,000 \\
\hline
\end{tabular}

Sumber: Analisis Data Primer

Tabel 1. menunjukkan hasil uji signifikan secara parsial bahwa variabel disiplin kerja, motivasi kerja, kepuasan kerja dan kompetensi kerja berpengaruh positif dan signifikan terhadap variabel komitmen organisasi. Uji ini dilakukan untuk mengetahui signifikansi pengaruh tiap-tiap variabel independen yaitu disiplin kerja, motivasi kerja, kepuasan kerja dan kompetensi kerja yang baik akan dapat meningkatkan komitmen organisasi pada karyawan di Rumah Sakit Ortopedi Prof. Dr. R. Soeharso Surakarta. Berdasarkan 
hasil analisis dapat diuraikan pengaruh tiaptiap variabel independen terhadap variabel dependen sebagai berikut:

Pengaruh disiplin kerja $\left(\mathrm{X}_{1}\right)$ terhadap komitmen organisasi. Hasil uji-t diperoleh nilai $t_{\text {hitung }}$ sebesar $3,125>\mathrm{t}_{\text {tabel }}(2,042)$ dengan nilai probabilitas $(\rho=0,002)<0,05$ berarti $\mathrm{H}_{2}$ diterima kebenarannya, artinya bahwa ada pengaruh yang signifikan antara disiplin kerja terhadap komitmen organisasi pada karyawan di Rumah Sakit Ortopedi Prof. Dr. R. Soeharso Surakarta, adapun besarnya pengaruhnya antara disiplin kerja terhadap komitmen organisasi pada karyawan sebesar 0,501, artinya jika disiplin kerja meningkat satu satuan maka komitmen organisasi meningkat sebesar 0,501 dengan asumsi variabel $\mathrm{X}_{2}, \mathrm{X}_{3}$, dan $X_{3}=0$.

Pengaruh motivasi kerja $\left(\mathrm{X}_{2}\right)$ terhadap komitmen organisasi. Hasil uji-t diperoleh nilai $t_{\text {hitung }}$ sebesar $7,161>t_{\text {tabel }}(2,042)$ dengan nilai probabilitas $(\rho=0,000)<0,05$ berarti H3 diterima kebenarannya, artinya bahwa ada pengaruh yang signifikan antara motivasi kerja terhadap komitmen organisasi pada karyawan di Rumah Sakit Ortopedi Prof. Dr. R. Soeharso Surakarta, adapun besarnya pengaruhnya antara motivasi kerja terhadap komitmen organisasi pada karyawan sebesar 1,072 , artinya jika motivasi kerja meningkat satu persen maka komitmen organisasi meningkat sebesar 0,301 dengan asumsi variabel $X_{1}, X_{3}$, dan $X_{4}=0$.

Pengaruh kepuasan kerja $\left(\mathrm{X}_{3}\right)$ terhadap komitmen organisasi. Hasil uji-t diperoleh nilai $t_{\text {hitung }}$ sebesar $6,606>t_{\text {tabel }}(2,042)$ dengan nilai probabilitas $(\rho=0,000)<0,05$ berarti $\mathrm{H}_{4}$ diterima kebenarannya, artinya bahwa ada pengaruh yang signifikan antara kepuasan kerja terhadap komitmen organisasi pada karyawan di Rumah Sakit Ortopedi Prof. Dr. R. Soeharso Surakarta, adapun besarnya pengaruhnya antara kepuasan kerja terhadap komitmen organisasi pada karyawan sebesar 0,777, artinya jika kepuasan kerja meningkat satu persen maka komitmen organisasi meningkat sebesar 0,777 dengan asumsi variabel $X_{1}, X_{2}$, dan $X_{4}=0$.
Pengaruh kompetensi kerja $\left(\mathrm{X}_{4}\right)$ terhadap komitmen organisasi. Hasil uji-t diperoleh nilai $t_{\text {hitung }}$ sebesar 5,002 $>\mathrm{t}_{\text {tabel }}(2,042)$ dengan nilai probabilitas $(\rho=0,000)<0,05$ berarti $\mathrm{H}_{4}$ diterima kebenarannya, artinya bahwa ada pengaruh yang signifikan antara kompetensi kerja terhadap komitmen organisasi pada karyawan di Rumah Sakit Ortopedi Prof. Dr. R. Soeharso Surakarta, adapun besarnya pengaruhnya antara kompetensi kerja terhadap komitmen organisasi pada karyawan sebesar 0,725 , artinya jika kompetensi kerja meningkat satu persen maka komitmen organisasi meningkat sebesar 0,725 dengan asumsi variabel $X_{1}, X_{2}$, dan $X_{4}=0$.

Berdasarkan hasil analisis tersebut terbukti bahwa hipotesis yang menyatakan "ada pengaruh yang signifikan variabel independen (disiplin kerja, motivasi kerja, kepuasan kerja dan kompetensi kerja) terhadap variabel dependen (komitmen organisasi) pada karyawan di RS. Ortopedi Prof. Dr. R. Soeharso Surakarta secara parsial", terbukti kebenarannya.

\section{Pengaruh disiplin kerja terhadap komitmen organisasi}

Berdasarkan pengujian hipotesis dengan uji t diketahui nilai sign. $0,002<0,05$, maka hipotesis pertama $\left(\mathrm{H}_{1}\right)$ terbukti kebenarannya, artinya ada pengaruh positif dan signifikan secara parsial antara disiplin kerja terhadap variabel terikat yaitu komitmen organisasi.

Kedisiplinan kerja yang ditunjukan karyawan juga mempengaruhi kinerjanya (Amran, 2009). Karena dengan kedisiplinan yang baik dengan cara mengikuti aturan-aturan perusahaan karyawan dapat mengerjakan tugasnya dengan tepat waktu dan tidak mengahambat bidang kerja lain dalam perusahaan. Menurut Mangkunegara (2015) disiplin pada dasarnya adalah kemampuan untuk mengendalikan diri dan mendukung sesuatu yang telah dibuat. Manajemen untuk menegakkan standar organisasi yang dinyatakan dalam pelaksanaan pedoman manajemen untuk memperkuat organisasi. Disiplin kerja sebagai salah satu alat yang digunakan oleh manajer untuk 
berkomunikasi dengan karyawan sehingga mereka bersedia mengubah perilaku dalam upaya mematuhi semua peraturan perusahaan dan norma-norma sosial yang berlaku sosial. tanpa pengecualian.

Hasil penelitian ini didukung oleh hasil penelitian sebelumnya yang dilakukan Amran (2009), Zesbendri dan Aryanti (2009) menyatakan bahwa disiplin kerja berpengaruh secara parsial terhadap komitmen organisasi. Di samping itu hasil penelitian ini diperkuat oleh penelitian yang dilakukan oleh Prabasari (2013) yang menyimpulkan bahwa tersapat pengaruh positif dan signifikan antara disiplin kerja terhadap komitmen organisasi.

\section{Pengaruh Motivasi Kerja terhadap Komitmen Organisasi}

Berdasarkan pengujian hipotesis dengan uji t diketahui nilai sign. $0,000<0,05$, maka hipotesis kedua $\left(\mathrm{H}_{2}\right)$ terbukti kebenarannya, artinya ada pengaruh positif dan signifikan secara parsial antara motivasi kerja terhadap variabel terikat yaitu komitmen organisasi. Hal ini berarti semakin baik dan meningkat dari motivasi kerja yang dimiliki karyawan maka semakin meningkat pula komitmen organisasi tersebut.Hal yang perlu dilakukan dalam upaya meningkatkan motivasi kerja terutama berkaitan dengan motivasi yang berhubungan dengan kegiatan baik itu pemasaran maupun hasil kerja garment terhadap kinerja seperti memberikan gaji yang lebih apabila ada karyawan yang melebihi target hasil kerja yang ditetapkan perusahaan, mengikutsertakan karyawan pada kegiatan-kegiatan sosial dan lain sebagainya, dengan disiplin kerja yang dimiliki karyawan akan menyebabkan karyawan menggunakan semaksimal mungkin terhadap hasrat untuk bekerja secara benar sehingga diperoleh komitmen organisasi yang maksimal pula.

Menurut Mangkunegara (2015) motivasi merupakan proses yang mendorong seseorang dalam menentukan intensitas, arah, dan ketekunan individu dalam upaya untuk mencapai target baik target individu maupun organisasi dimana ia berada. Hubungan motivasi dengan komitmen organisasi dapat diuaraikan sebagai brrikut semakin tinggi motivasi seseorang untuk bertahan dan terlibat dalam suatu organisasi maka akan semakin meningkat komitmen seseorang, Motivasi kerja yang timbul dapat dipengaruhi oleh beberapa faktor, antara lain, atasan, fisik fasilitas, kebijakan, aturan, penghargaan dan uang non-tunai layanan, jenis bekerja dan tantangan.

Hasil penelitian ini sejalan dengan penelitian yang dilakukan oleh Nurcahyo (2011) menyatakan bahwa motivasi berpengaruh signifikan secara parsial terhadap komitmen organisasi, dan juga Prabasari (2013) yang menyatakan bahwa ada pengaruh positif dan signifikan variabel motivasi terhadap komitmen organisasi. Hasil penelitian ini sejalan dengan penelitian yang dilakukan oleh Sriekaningsih dan Setyadi (2008) mengenai pengaruh kompetensi, motivasi dan budaya organisasi kearah komitmen organisasi dan kinerja pada Dosen State University di Kalimantan Timur tahun 2015, hasil penelitiannya menyimpulkan bahwa ternyata motivasi, disiplin kerja dan kepuasan kerja mempunyai pengaruh terhadap prestasi kerja pegawai, sehingga dapat dijelaskan pula bahwa disiplin kerja dan kepuasan kerja dapat meramalkan perubahan pada kinerja pegawai tersebut. Secara teori motivasi mempengaruhi aktivitas dan tujuan organisasi, dorongandorongan yang ada pada diri seseorang yang mengarah pada tercapainya tujuan, dorongan yang paling kuat menghasilkan adanya perilaku, baik yang berupa aktivitas terarah ke tujuan atau aktivitas tujuan, adanya motivasi maka pegawai akan memberikan rangsangan yang positif terhadap pekerjaannya, sehingga disiplin kerja pegawai akan mempe-ngaruhi prestasi atau kinerjanya, demikian halnya adanya kepuasan kerja secara teori kepuasan kerja mencakup pemahaman pegawai terhadap misi, komitmen, komunikasi, sense of belonging (rasa memiliki) dan penghargaan yang proporsionalakan mendorong terciptanya efektivitas organisasi. Hal ini dapat ditempuh dengan memberikan dorongan yang positif 
serta memberikan interaksi antara sikap, kebutuhan, persepsi dan keputusan yang ada pada diri pegawai dalam melaksanakan pekerjaannya, sebab motivasi mendorong jiwa dan sikap mental manusia sehingga memberikan energi kearah pencapaian suatu tujuan yang telah ditentukan.

\section{Pengaruh Kepuasan Kerja terhadap Komitmen Organisasi}

Berdasarkan pengujian hipotesis dengan uji t diketahui nilai sign. $0,005<0,05$, maka hipotesis ketiga $\left(\mathrm{H}_{3}\right)$ terbukti kebenarannya, artinya ada pengaruh positif dan signifikan secara parsial antara kepuasan kerja terhadap variabel terikat yaitu komitmen organisasi. Hal ini berarti semakin baik kepuasan kerjanya maka semakin meningkat pula komitmen organisasi tersebut. Hasil penelitian ini mendukung teori yang dikemukakan oleh Robbins (2008) bahwa kepuasan kerja dapat menyatukan berbagai karakteristik individu kedalam suatu wadah perilaku yang didasarkan nilai-nilai kebersamaan dan diyakini kebenaranya. Upaya untuk meningkatkan komitmen organisasi diantaranya karyawan telah menggunakan metode kerja yang efektif, karyawan mempunyai kemampuan untuk menyelesaikan pekerjaan, karyawan cukup memahami terhadap pekerjaan yang dibebankan kepada pimpinan atau perusahaan, dan lain-lainnya. Hal ini dapat ditempuh dengan memberikan penjelasan dari perusahaan/pimpinan untuk bekerja lebih efektif, memahamkan karyawan untuk bekerja lebih baik dari hari kemarin, dan memberikan kebijakan kepada karyawan untuk mampu bekerja sesuai dengan arahan dan metode yang benar yang sudah ditetapkan oleh perusahaan.

Hasil penelitian ini sejalan dengan hasil penelitian yang dilakukan Amran (2009) bahwa terdapat pengaruh positif antara kepuasan kerja dengan kinerja pegawai Dinas Kebudayaan dan Pariwisata di Jawa Timur. Dan penelitian yang dilakukan oleh Usman (2011) terdapat pengaruh sangat kuat dan signifikan antara kepuasan kerja terhadap komitmen organisasi pada Industri Roko di Jawa Timur. Jadi kepuasan kerja mempunyai hubungan secara positif dan searah berpengaruh terhadap kinerja, dengan demikian bahwa kepuasan kerja yang kuat akan menghasilkan kinerja yang positif.

\section{Pengaruh Kompetensi Kerja terhadap Komitmen Organisasi \\ Berdasarkan pengujian hipotesis dengan} uji t diketahui nilai sign. $0,005<0,05$, maka hipotesis keempat $\left(\mathrm{H}_{4}\right)$ terbukti kebenarannya, artinya ada pengaruh positif dan signifikan secara parsial antara kepuasan kerja terhadap variabel terikat yaitu komitmen organisasi. Hal ini berarti semakin baik kepuasan kerjanya maka semakin meningkat pula komitmen organisasi tersebut. Hasil penelitian ini mendukung teori yang dikemukakan oleh Streuner dan Bjoruest (1998) kompetensi merupakan kemampuan individu melakukan tugas-tugas yang telah ditetapkan pimpinan kepadanya. Kompetensi dipahami sebagai pengetahuan, keterampilan, dan identitas profesional sesuai komitmen karyawan yang bersangkutan, Menurut Michael Zwell (2005) ada lima kategori kompetensi, yaitu: task achievement, relationship, personal attribute, managerial dan leadership.

Hubungan kompetensi kerja terhadap komitmen organisasibahwa semua kemampuan dan keterampilan melaksanakan tugas yang diberikan atasan, hubungan yang baik dengan atasan maupun sesama akan sangat berpengaruh terhadap peningkatan komitmen organisasi.

\section{Pengaruh Disiplin Kerja, Motivasi Kerja, Kepuasan Kerja dan Kompetensi Kerja terhadap Komitmen Organisasi}

Berdasarkan pengujian hipotesis dengan uji $\mathrm{F}$ diketahui nilai sign. $0,000<0,05$, maka hipotesis kelima $\left(\mathrm{H}_{5}\right)$ terbukti kebenarannya, artinya ada pengaruh signifikan secara bersama-sama antara disiplin kerja, motivasi kerja, kepuasan kerja dan kompetensi kerja terhadap variabel terikat yaitu komitmen 
organisasi. Hal ini dikarenakan karyawan berkerja dengan sesuai dengan tugas dan tanggung jawab, berkerja sesuai dengan aturan yang berlaku, menggunakan waktu dengan baik, menyelesaikan pekerjaan tepat waktu dan mematuhi perintah atasan serta taat dan tertib dalam melaksanakan tugas dan tanggung jawab yang diberikan kepadanya. Hasil penelitian ini mendukung terori yang dikemukakan oleh Hasibuan (2009). Dengan disiplin yang baik akan mencerminkan besarnya tanggung jawab seseorang terhadap tugas-tugas yang diberikan karena disiplin merupakan operatif manajemen sumber daya manusia yang terpenting karena semakin baik disiplin karyawan, semakin tinggi prestasi kerja yang dapat dicapainya, dan tanpa disiplin karyawan yang baik sulit bagi organisasi mencapai hasil yang optimal.

Demikian juga motivasi, keberhasilan suatu organisasi sangat dipengaruhi oleh faktor angota-anggotanya dalam melakukan fungsinya masing-masing. Faktor yang sangat berpengaruh terhadap kualitas kerja dari anggota organisasi adalah komitmen organisasi yang dimiliki. Motivasi adalah suatu proses yang mendorong, mengarahkan dan memelihara perilaku manusia ke arah pencapaian suatu tujuan. Batasan tersebut memperlihatkan kepada kita bahwa setiap gerak individu sadar atau tidak pasti memiliki motivasi (Djatmiko, 2005).

Di samping kedisiplinan dan motivasi, faktor budaya juga berpengaruh signifikan terhadap timbulnya komitmen organisasi. Hal ini sesuai dengan teori yang dikemukakan oleh Robbins (2008) bahwa kepuasan kerja dapat menyatukan berbagai karakteristik individu kedalam suatu wadah perilaku yang didasarkan nilai-nilai kebersamaan dan diyakini kebenaranya.

Dari hasil penelitian tersebut disimpulkan bahwa secara simultan terdapat pengaruh kedisiplinan, motivasi kerja dan kepuasan kerja terhadap komitmen organisasi. Hasil penelitian ini sejalan dengan penelitian yang dilakukan oleh Widiati (2012), yang menyimpulkan bahwa secara simultan terdapat pengaruh signifikan motivasi kerja, disiplin kerja dan kepuasan kerja terhadap kinerja pegawai kesehatan di RS Secanti Gisting. Selain itu hasil penelitian ini juga diperkuat oleh penelitian yang dilakukan oleh Novitasari (2013) yang menyimpulkan bahwa terdapat pengaruh signifikan secara simultan antara motivasi, kepuasan kerja dan disiplin kerja terhadap kinerja pegawai di Dinas Perindustrian dan Perdagangan Provinsi Jawa Tengah.

\section{Penutup}

Berdasarkan pada penyajian hasil penelitian serta pembahasan hasil penelitian, maka dapat dikemukakan beberapa kesimpulan sebagai berikut. Disiplin kerja berpengaruh positif dan signifikan terhadap komitmen organisasi pada karyawan Rumah Sakit Ortopedi Prof. Dr. R. Soeharso Surakarta. Motivasi kerja berpengaruh positif dan signifikan terhadap komitmen organisasi pada karyawan Rumah Sakit Ortopedi Prof. Dr. R. Soeharso Surakarta. Kepuasan kerja berpengaruh positif dan signifikan terhadap komitmen organisasi di Rimah Sakit Ortopedi Prof. Dr. R. Soeharso Surakarta. Kompetensi kerja berpengaruh positif dan signifikan terhadap komitmen organisasi pada karyawan Rumah Sakit Ortopedi Prof. Dr. R. Soeharso Surakarta. Disiplin kerja, motivasi kerja, dan kepuasan kerja berpengaruh signifikan secara bersama-sama terhadap komitmen organisasi pada karyawan Rumah Sakit Ortopedi Prof. Dr. R. Soeharso Surakarta.

Saran dalam penelitian ini sebagai berikut. Bagi Karyawan berkaitan dengan motivasi kerja diharapkan dapat meningkatkan motivasi kerja terutama berkaitan dengan kemampuan yang berhubungan dengan kegiatan penjualan maupun penyelesaian kerja konfeksi seperti mengikutsertakan karyawan dalam pelatihanpelatihan/diklat dan studi banding bagi karyawan baru agar mampu melaksanakan tugasnya dengan semaksimal mungkin. Pimpinan dapat memberikan motivasi tinggi terhadap kinerja diri karyawan dengan cara memberikan penghargaan bagi yang 
mempunyai kinerja baik, serta memberikan pembinaan bagi yang berkinerja rendah, untuk itu pihak rumah sakit perlu membina hubungan kerja yang baik dan selaras antara pimpinan dan karyawan sehingga akan timbul kebersamaan dan kerjasama yang baik sehingga dapat meningkatkan kinerja perawat. Pimpinan perlu menggali faktorfaktor yang dapat mendukung terbentuknya komitmen organisasi seperti memperhatikan kepuasan perawat/karyawan, kebijakan yang transparan dalam pembagian remunerasi, jaminan kesehatan, pengembangan karier, sehingga mampu menghasilkan karyawan yang berkinerja yang baik serta mempunyai komitmen yang tinggi terhadap rumah sakit. Pimpinan memberikan dukungan yang tinggi bagi karyawan di tempat kerja sehingga menyebabkan mereka memiliki komitmen yang tinggi pada pekerjaannya sekaligus memungkinkanrumahsakitdapatmenciptakan kepuasan kerja karyawan sehingga akan meningkatkan kinerja rumah sakit yang pada akhirnya akan menguntungkan rumah sakit itu sendiri. Bagi Peneliti selanjutnya diharapkan dapat meneliti faktor-faktor yang mempengaruhi komitmen organisasi selain faktor disiplin kerja, motivasi kerja, kepuasan kerja dan kompetensi kerja, misalnya faktor lingkungan kerja, kepemimpinan, dan karakteristik individu. Penelitian ini bisa diharapkan menggeneralisasi secara luas beberapa pengaruh yang dapat memberikan kontribusi terhadap faktor yang berpengaruh terhadap komitmen organisasi.

\section{Daftar Pustaka}

Amran. 2009. Pengaruh Disiplin Kerja Terhadap Kinerja Pegawai Departemen Sosial Kabupaten Gorontalo. Jurnal Ichasan Gorontalo. Vol. 4, No. 2, Hal 2397-2413.

Brahmasari, I. A. dan Suprayetno, A. 2008. Pengaruh Motivasi Kerja, Kepemimpinan dan Budaya Organisasi Terhadap Kepuasan Kerja Karyawan serta Dampaknya pada Kinerja Perusahaan (Studi kasus pada PT. Pei Hai International Wiratama Indonesia). Jurnal Manajemen dan Kewirausahaan. Vol. 10, No. 2. September 2008: 124-135.

Gibson, I. D.. 2005. Organisasi, alih bahasa Nunuk Adiarni, edisi Kedelapan, Jakarta: Binarupa Aksara

Handoko, T. H. 2010. Manajemen Personalia dan Sumber Daya Manusia. Yogyakarta: BPFE. Hardjosoedarmo. S. 2006. Total Quality Manage-ment. Yogyakarta: Penerbit Andi.

Hasibuan, M.S.P. 2006. Manajemen Sumber Daya Manusia. Edisi Ketujuh. Jakarta: Bumi Aksara.

Ranupandoyo, H. dan Husnan, S. 2007. Manajemen Personalia, BPFE, Yogyakarta: BPFE

Hidayat. 2007. Pengaruh Motivasi Kerja terhadap Kinerja Karyawan dengan Variabel Moderator Etos Kerja Spritual. Jurnal Ekonomi dan Manajemen. Volume 8, Nomor 1. Februari 2007.

Luthans. 2007. Perilaku Organisasi. Yogyakarta: Andy Offset.

Miner, J.B. 2006. Organizational Behavior: Performance and Productivity, First Edition. Inc. New York: random House, Inc

Moekiyat. 2007. Manajemen Kepegawaian. Yogyakarta: BPFE UGM.

Novitasari, 2013. Pengaruh Motivasi, Budaya Organisasi dan Disiplin Kerja terhadap Kinerja Pegawai di Dinas Perindustrian dan Perdagangan Provinsi Jawa Tengah. Jurnal Ekonomi dan Bisnis. Semarang: Unsep. 
Nurcahyo, A. 2011. Analisis Variabel-Variabel Yang Menpengaruhi Kinerja Karyawan Pada PT. Quadra Mitra Perkasa Balikpapan. Jurnal Eksis. Vol.7 No.2, Hal. 1972 - 1982.

Olsen, R.W. 2006. Seni Berpikir Kreatif: Sebuah Pedoman Praktis. Jakarta:Erlangga

Prabasari. 2013. Pengaruh Motivasi, Disiplin Kerja dan Komunikasi terhadap Kinerja Karyawan pada PT. PLN (Persero) Distribusi Bali”. Jurnal Ekobis. Fakultas Ekonomi Universitas Udayana (UNUD). Volume

Reksohadiprodjo, H.T. 2007. Perilaku Organisasi Konsep Dasar dan Aplikasinya, Jakarta: PT Raja Grafindo Persada.

Robbin, S., 2008, Perilaku Organisasi, Konsep, Kontroversi, Aplikasi, Alih bahasa Handyana Pujaatmaka. Edisi Kedelapan. Jakarta: Prihallindo

Sekaran, U. 2007. Research Methods for Businnes. New York: John Wiley \& Sons. Inc.

Setiadi. 2008. Metode Kuantitatif untuk Pengendalian Manajemen. Yogyakarta: Bina Ilmu.

Stoner, J.A.F. 2006. Human Resources Management. New York: West Publishing Company.

Sudarmayanti. 2011. Manajemen Sumber Daya Manusia Reformasi Birokrasi dan Manajemen Pegawai Negeri Sipil. Bandung: Refka Aditama.

Sugiyono. 2008. Metodologi Penelitian. Bandung: Alfabeta.

Timpe, A. D. 2005. Kinerja, Seri Ilmu dan Seni Manajemen Bisnis. Alih Bahasa Sofyan Cikmat. Jakarta: PT. Elex Media Komputindo,

Wibowo. 2002. "Hubungan Karakteristik Pekerjaan terhadap Kinerja (Studi pada Kantor Unit Caang BRI Pattimura Semarang)". Tesis Magister Manajemen Undip. (Tidak dipublikasikan). Semarang: UNDIP.

Winardi, 2010, Motivasi dan Pemotivasian dalam Manajemen, Cetakan Pertama, Jakarta: PT. Raja Grafindo Persada. 